\title{
King Lear: A Negatively Capable Outsider
}

\author{
Hossein Salimian Rizi \\ University of Vienna, AUSTRIA \\ e-mail: hsalimian3075@gmail.com
}

\begin{abstract}
Negative capability, John Keats's coined term, defined the ideal poet as the one capable of being in uncertainties and mysteries without any reaching after fact and reason. He insisted poets let the mind be a thoroughfare for all thoughts, by holding on no fixed identity but metamorphic identities. Although, Keats found the ideal quality of a poet in Shakespeare, it did not appear far from logical to investigate it in the characters of his plays, specifically King Lear, since he underwent changes throughout the story. King Lear cut across his egoistic self to enrich his receptivity to the actual vastness of life experience after he became an outsider in his erstwhile kingdom. In this article, I would employ the concept of negative capability to take a step further ahead of its theoretically stipulated implications and investigate it on the character of King Lear.
\end{abstract}

Keywords: Negative capability; identity; outsider

\section{NEGATIVE CAPABILITY}

John Keats lived a short life, though the volume of literary works he produced is outstanding. He was an English Romantic poet, who took on the challenges of a range of poetic forms from the sonnet and the Spenserian romance, to the Miltonic epic. In his correspondence, he proposed his coined ideas such as the "chameleon poet" and "negative capability." Amongst his writings, his letters are highly regarded within the canon of English literary correspondence, since they reflect on the background and composition of his poetry and talk about negative capability as a central part of his poetics. Despite making fleeting appearances in his correspondence, some of his ideas - particularly negative capability and the chameleon poet - have gained firm footing in Romantic studies. Keats's letters, however, represent a wide-ranging explanation of the qualities attributed to the chameleon poet and the concept of negative capability. These two concepts, according to Keats, have to do with the determining qualities of an ideal poet. Keats at times turns out to be driven by his intense emotions in his writings; nonetheless it is possible to follow the chronological progress of his ideas -which implicitly burgeons in his mature works-about ideal poets.

Keats states that an ideal poet, identified as the chameleon poet, does not settle upon any systematic philosophy or mentality, which holds back imaginative creativity and hinders receptivity to the actual vastness and complexity of life experience. In Keatsian aesthetics, a poet should avail himself/ herself with negative capability, which is a phrase coined by Keats and just once employed briefly in a letter to his brothers, George and Thomas Keats, on December 21, 1817. Negative capability talks about the poetic self and the necessity of a dynamic identity. This concept, according to Keats, characterizes the capacity of the greatest writers to follow a vision of artistic beauty as contrasting with philosophical certainty and pursuit of fact and reason. Negative capability is "when a man is capable of being in uncertainties, mysteries, doubts, without any irritable reaching after fact and reason," which defines "A Man of Achievement especially in Literature," and which "Shakespeare possessed so enormously" (Keats, 2002, p. 60). Keats insists that an ideal poet should possess negative capability, the aesthetics of uncertainties and doubts. In a broader sense, negative capability suggests openness to the actual vastness and complexity of experience without intervention of systematic philosophies or mentalities. But the prerequisite for possession of this openness is the personal strength to abandon the comfortable enclosure of doctrinaire knowledge, which is persistently withholding the poetic individuality from experiencing a broad span of phenomena beyond immediate perceptions.

Walter Jackson Bate, in his The Stylistic Development of Keats (1958), gives a descriptive unfolding of 
Keats's literary craftsmanship and offers alignments of technical evolution with changes of Keats's mind. In this book, he produces an analytical account of negative capability and addresses the uncertainty in one's life, "where no one system or formula can explain everything," therefore what follows is "an imaginative openness of mind and heightened receptivity to reality in its full and diverse concreteness," which unconsciously implicates "negating one's own ego" (Bate, 1958, p.249). In this case, it should be noted that 'capable' and 'irritable' which are emphasized in Keats's definition of negative capability are meant to extend our capability to take on new identities; they urge us to moderate our self-centeredness, compromise on a wide spectrum of contrary claims, and embrace no static reasoning, which ipso facto constrains the faculty of imagination. In other terms, it urges a poet to take on all selves while standing above all of them without being specifically any of them; a self which is elastic and infinitely agile that stands above any of its experiences, and hence the annihilation of a fixed identity.

Keats often refers to his sense of identification with natural phenomena and absorption into other states of being. He deems "the loss of identity as a means of encountering the nature of others," which suggests "a deep-seated reaction against the certainty of selfhood" (Whale, 2005, p. 8). Absolute certainty of selfhood depreciates other experiences beyond immediate perceptions and encloses a poet's span of experience within a short range. Transcending the enclosure of immediate experiences, according to Keats, posits a metamorphic identity. In other terms, the ideal poet has metamorphic identities, which supply him/her with persistent sympathetic identification with nature or human beings alike. Friedrich Schlegel (17721829), a German Romantic philosopher and literary critic, has a description of transcendental self which has pronouncements with Keats's metamorphic identity. The transcendental self, as Pau de Man explains Schlegel's idea, is what we think of "as some kind of super-, transcendental self which man approaches, as something that's infinitely agile, infinitely elastic ... as a self that stands above any of its particular experiences and toward which any particular self is always under way" $(1996,175)$. This resonates with Keats's negative capability where he talks about Shakespeare as the man who has a metamorphic identity, which can take on all selves while standing above all of them without being specifically any of them; a self which is elastic, mobile and infinitely agile that stands above any of its experiences.

This Keats remarks to Reynolds in a letter of April 27, 1818: "I lay awake last night listening to the Rain with a sense of being drowned and rotted like a grain of wheat" (Keats, 2002, p.118). Such identification is an outstanding trait the chameleon poet maintains, being a negatively capable poet who, "is not itself - it has no self - It is everything and nothing - It has no character - it enjoys light and shade; it lives in gusto, be it foul or fair, high or low, rich or poor, mean or elevated - It has as much delight in conceiving an Iago as an Imogen" (Keats, 2002, p.195). Accordingly, the ideal poet has an elastic and agile self that allows him/her to take on various identities while standing above all of them without being specifically any of them. The ideal poet should yearn for dynamic and fluid identities. In speaking of such a chameleon poet - who is utterly devoid of any fixed character as a supplementary quality for negative capability, Keats notes the successful extinguishment of ego and self-identity, thus "a poet is the most unpoetical of anything in existence, because he has no Identity - he is continually in for and filling some other body" (Keats, 2002, p.195). So, a poet has an acquisitive and all-embracing identity which neither belongs to any fixed mentality and philosophy, nor holds back from any of them, but he/she treads on an imaginative thoroughfare which provides a vast span of experiences, while standing above all of them. Keats shares such an experience as 'filling some other body' in a letter to Richard Woodhouse on October 27, 1818:

When I am in a room with People, if I ever am free from speculating on creations of my own brain, then not myself goes home to myself, but the identity of everyone in the room begins to press upon me that I am in a very little time annihilated [emphasis added]. (Keats, 2002, p.195)

Annihilation stands out as the key element to attain metamorphosis of self. It occurs once the poet is free from speculation. Richard Benton conceives of Keats's self-annihilation not as a result "in the inflation of his personal ego, but in a genuine loss of self-identity and in a discovery of his True Self' (Benton, 1966, p.46). The poetic self is not to be inflated in an egotistic sense, but to lose the fixed identity in pursuit of a metamorphic identity. Therefore, identity formation, in terms of ontological argument, should continually run on a becoming path, rather than that of being. Keats attempts to embrace an antithetical poetical character by whose very composition he would dismiss private interests from the range of his poetic practice. In a letter to Fanny Brawne on July 25, 1819, he observes the selfannihilating absorption intensified by love when "you absorb me in spite of myself" (Keats, 2002, p.318). This remark bears witness to Keats's constant effort to 
make the self takes on numerous identities through poetry. Inferred from his correspondence, Keats's aspirations account for disinterestedness that transforms pathos into a real, tragic vision by means of negative capability, which ultimately help the mind retain an openness that borders on disinterestedness.

Relevant here is the consideration of the power of sympathy, both moral and aesthetic, which is a legacy that Coleridge, Wordsworth, Hazlitt, and Keats all shared and it became the cornerstone of English Romanticism, insofar as it is contingent on the idea of imagination. Sympathy is aroused with the imagination providing a way for a person to imagine human feelings, which enables him/her to feel the sufferings of others and so is inspired to act of benevolent charity. Sympathy gained momentum in the Romantic age. It was "the visible outward sign of one's awareness of others and of the community; it was a necessary emotional gift for anyone of refined temperament or sentiment" (Fay, 1998, pp. 6-7). Samuel Johnson, the Enlightenment Man of Reason, believed that emotions could thwart moral judgment and lead to social decay. The Romantic emphasis on emotions, however, is not a rejection of Enlightenment reason, only a strong alternative to it, since affections can be rational as well as emotional responses to artistic endeavor. Therefore, the import of romantic consideration of emotion as a means of influential insight is characteristically represented by sympathy in ethical and aesthetic theory. It is a main tenet of English Romantic criticism to reflect on the capability of imagination, through an effort of sympathetic identification with objects, so the sympathetic imagination realizes the distinctive nature, identity, or truth of the objects.

With that said, Romantic aesthetics invariably constitute the sympathetic nature of imagination; in other terms, the poet is "annihilated by throwing himself into the object or the person he imitates, and thus the poet's own subjective nature is absorbed into the objective world" (Engell, 1981, p.146). Sympathy provided imaginative ground for Romantics, and Romantics directed their outward subjective experience to an appreciation of natural objects. In English Romantic thought, sympathy has a broad application in re-establishing a bond of union among humankind, as well as between man and the external nature. Keats maintains that negative capability provides poets with metamorphic identities so that they can sympatheticcally merge with their subjects through imagination. "The Sun - the Moon - the Sea, and men and women," Keats writes, "who are creatures of impulse, are poetical," about which poets noticeably have "an unchangeable attribute" (Keats, 2002, p.195). This refutes the claim that poets ought to reduce the inexplicable mysteries of the world to make sense of them. According to Keats, they should remain in mystery and doubt to appreciate the world's beauties. In other words, poets should dissolve their static identities and subjectivities and merge with the subjects' identities. A negatively capable poet, Mark Sandy argues, celebrates the "uncertainties of roaming indistinct borders between the territories of objective and subjective truth claims," and dismisses "rigid Enlightenment explanations of reality as static" (Sandy, 2005, p.26). Therefore, negative capability blurs the territories of subjectivity and objectivity via the poetic imagination, and the subject's elastic and agile self merges with the object. Keats shares such an experience with Bailey in 1817: "if a Sparrow come before my Window, I take part in its existence and pick about the gravel" (2002, p.55). By means of imagination, Keats's subjectivity merges with the objectivity of the sparrow.

Related to Keats's ideas of negative capability and the chameleon poet is the metaphor of the chamber of maiden thought, which is also a key trope in understanding Keats's poems. In a letter to Reynolds on May 3, 1818, he writes: "I compare human life to a large Mansion of Many Apartments, two of which I can only describe [...] The first we step into we call the infant or thoughtless Chamber, in which we remain as long as we do not think," but from this state of innocence, we are driven into the "Chamber of Maiden-Thought," where knowledge is exhilarating but soon discloses that "the World is full of Misery and Heart-break, Pain, Sickness and oppression" (Keats, 2002, p. 124). Here, Keats suggests people's capability of embracing different levels of thought, the first of which is 'the thoughtless chamber' wherein they do not reflect on the world around them, but remain there free from bothering themselves with speculating and thinking. Even though the door to move on to the next 'apartment' is open, they do not long to think any deeper to make way to the next level of thought, which is 'Chamber of Maiden-Thought.' However, having moved into this level of thought, they run into choices of direction and just understand that there are more than a few different dark passages. They, however, realize that among the effects of this tremendous transition is that of "sharpening one's vision into the heart and nature of Man" (Keats, 2002, p.124). Yet the realization, according to Keats, commands a remarkable distance from one's egotistical passions to remain in doubts and mystery without making definite efforts to draw an immovable and static conclusion. At the threshold of the Chamber of Maiden-Thought, an ideal poet begins to keep personal speculations and interests at distance and 
pace steadily on an imaginative thoroughfare, free from ideological bounds.

Selfishness and decentralization of personal interests briefly mark negative capability, which gradually surface in the character of King Lear after he becomes an outsider. Although Keats finds the ideal quality of a negatively capable poet in Shakespeare not in the characters of his plays, it does not appear far from logical to investigate negative capability in the characters of his plays, specifically in King Lear, as he undergoes noteworthy changes throughout the story and ultimately cuts across his egoistic self to enrich his receptivity to the actual vastness and complexity of life experience.

\section{KING LEAR'S ASSUMPTION OF NEGATIVE CAPABILITY}

Around 1960, the play King Lear (1606) regained its lead in literary criticism. In the 1960s, "the play became Shakespeare's bleakest and most despairing vision of suffering" (Foakes, 1994, pp. 3-4). Yet, the redemption side of the play has not simply been discarded, due to the existence of ample indications in the play to suggest it. Keats was enormously impressed by the sharpened vision - in Keats's words - King Lear had attained after the severe hardships he had borne. The play's massive influence lies "behind many of his [Keats's] meditations on poetic creativity and upon human suffering" (White, 1987, p.169). He evidently bears King Lear's fate in mind when comparing the original nature of man to "a poor forked creature subject to the same mischances as the beasts of the forest, destined to hardships and disquietude of some kind or other" (Keats, 1899, 369); or when he celebrates the exigency of pain and troubles in the world to uplift the soul in a variety of his letters, the most conspicuous of which is the one written in 1819 to George and Georgiana Keats: "Do you not see how necessary a World of Pains and troubles is to is to school an intelligence and make it a soul?" (Keats, 1899, 291). He subordinates the elevation of soul to the extent of pains and troubles it bears. It also surfaces in his two coined concepts of negative capability and the chameleon poet, which together propose a dynamic and elastic poetic self. Inferred from Keats's writings, pains of the outer world mark a significant initiation in this dynamic process, through which King Lear gets to finally see and acknowledge the truth. The concepts, as mentioned above, also represent Keats's involvement with discourses of identity and self-formation. Likewise, discourses of self-transformation and change of identity constitute King Lear's speech in the play. The chameleon poet does not rely on any systematic philosophy or mentality but on a metamorphic identity, which is the main constituent of negative capability; say no irritable reaching after fact and reason, but to remain in uncertainty and mystery. King Lear shows signs of an elastic self, which directs him toward negating the egoistic self and finding the truth, but this calls for an excruciating self-constructing journey.

For Keats, King Lear's life story represents a lifelong journey through his own inwardness during a very short span of time. The play, in his recognition, is marked by "action, energy and spontaneous outbursts rather than introspection or sustained reflectiveness" (White, 1987, p.186). King Lear undergoes a radically progressive conflict between his outwardness and inwardness, which gradually turns his overriding selfassurance into a sublime vision of human despair, which emerges in his address to Tom the beggar: "Unaccommodated man is no more but such a poor, bare, forked animal" (Shakespeare, 2000, II. iv. 1145). To King Lear, an uncivilized man is no more than a poor, naked, two-legged animal, yet he concludes that this two-legged animal (Tom) represents true humanity, since he wears no perfume and fancy clothes that society uses to hide what people are really like. Inferred from his speech, a fresh vision develops in the king's personality. Staring at the near-naked Tom in the midst of a raging storm, he regards all of humanity as being reduced to this bare level and thinks that the way to perceive man's essence is to diminish him to the lowest common denominator, in particular to take off his clothing, symbolic of all the additions with which civilization tries to raise human beings above the level of beasts. Having gained a profoundly disillusioning experience with his ungrateful daughters, Lear learns to perceive beyond the appearances on which human beings conventionally pride themselves. Accordingly, he starts to strip himself off his clothing, to cast aside the customary trappings of his kingly status, and thereby bring himself in line with the diminished image of humanity he sees embodied in Poor Tom.

Disposing of his kingdom, King Lear wishes to "shake all care and business from" his age "conferring them on younger strengths" (Shakespeare, 2009, 1, 1, 42-3), and he divides his kingdom between Regan and Goneril, even though, Lear is advised against the division. Kent berates Lear for his hasty and gullible decision and minds the ensuing consequences:

Think'st thou that duty shall have dread to speak When power to flattery bows? To plainness honor's bound

When majesty falls to folly. Reserve thy state,

And in thy best consideration check

This hideous rashness. Answer my life my judgment, 
Thy youngest daughter does not love thee least, Nor are those empty-hearted whose low sound Reverbs no hollowness (Shakespeare, 2009, 1, 1, 164-173).

Nevertheless, he divides his kingdom and disowns Cordelia. He is blind to Cordelia's ingenuous love and her sisters' empty-hearted flattery, despite Kent's bold insistence on his reconsideration of forsaking Cordelia: "See better, Lear; and let me still remain / The true blank of thine eye" (Shakespeare, 2009, 1, 1, 180-1), but Kent ought to "come not between the dragon and his wrath" (Shakespeare, 2009, 1, 1, 136). Lear's eyes must seemingly see dreadful occurrences in the near future and he should evidently sink relatively into sorrow to gain the necessary knowledge to grasp the truth. This, according to Keats, sharpens his sense of identification and sympathy to nature and human being.

John Keats clearly reflects on Lear's intellectual progress when he feels "a little change" in his "intellect" that he cannot "bear to be uninterested or unemployed" because "nothing is finer for the purposes of great productions than a very gradual ripening of the intellectual powers" (Keats, 1899, p.282). His insistence on rearing the intellect is remarkably widespread in his writings. Keats maintains that a sort of inspiration "appeared to demand the prologue of a sonnet," that later is called "On Sitting Down to Read king Lear Once Again," in which he subtly concentrates on the necessity of conflict with impending mortality and clash with passiveness to ripen intellect; precisely the journey that King Lear goes on to 'school' his intellect (Keats, 1899, 282). Tolerating unmitigated suffering, King Lear rears the soul in a way that leads to a modified knowledge of human limitations and human potential. King Lear is the depiction of a hero thinking his way toward self-discovery. The initial sparks of selfdiscovery appear after Goneril demands he dismiss half of his knights for their rowdiness and he replies:

Does any here know me? This not Lear.

Does Lear walk thus, speak thus? Where are his eyes?

Either his notion weakens, his discernings Are lethargied - Ha! Waking? 'T is not so.

Who is it that can tell me who I am? (Shakespeare, 2009, 1, 4, 231-36)

Deeply uneasy about Goneril's slackening respect, he leaves for Regan's home, in the desperate hope that Regan would welcome him and his followers with hospitality, but to his disappointment, Regan and Cornwall refuse to see him and they eventually reduce the number of his servants to none: "What need you five and twenty, ten, or five / To follow in a house where twice so many / Have a command to tend you?" (Shakespeare, 2009, 2, 4, 301-3). This initiates the outsider status about to befall him. Enraged and heartbroken, he rushes out into a harsh storm. From now on, he starts to attain "high intelligence and greatness of spirit completely outside the definition of such a term as dotard" (Schoff, 1962, p.162). This foregrounds King Lear's potential for enduring the extinguishment of self-worth and selfidentity in pursuit of self-discovery, a means of which, in Keats's premise, is through committing to negative capability, as it promises dynamic and fluid identities via abstaining from attachment to any static and decisive identity. The elastic and fluid characteristic is reiterated in William Hazlitt's The Round Table (1817). Hazlitt asserts that Shakespeare empathizes with his fictional characters by being "now Hamlet, now Othello, now Lear, now Falstaff, now Ariel," thus, in the "tumult and rapid transitions of this waking dream, the author [Shakespeare] could not easily find time to think of himself, nor wish to embody that personal identity [emphasis added] in idle reputation after death" (Hazlitt, 1991, p.76). In other terms, Shakespeare's metamorphic identity - in Keats's words - refrains from succumbing to any static identity, and uplifts Shakespeare's spirit so high that he did not seem to worry about 'idle reputation' after death.

According to Keats, Shakespeare was capable of remaining in uncertainty without doggedly resolving any heated dispute. King Lear is likewise a character who eventually gains a metamorphic identity and overcomes his irresistible reaching after peremptory commands once he starts being alienated from his own kingdom. This is an acute import of King Lear's outgrowth of negative capability throughout the story. At the outset of the play, Lear is so devoted to his royal majesty as if it were no word but his. He, however, starts facing a world of troubles, sinking into doubts and mystery, negating his egoistic self and finally acknowledging the truth. His rhetoric and soliloquies indicate the momentum his identity gained by virtue of the world of pains to triumph over his self-centeredness.

The approximate indications of negative capability emerge in the striking questions Lear poses: "Does any here know me? Why, this is not Lear" (Shakespeare, 2009, 1, 4, 231). From this rhetorical question onwards, his kingly grandeur begins to collapse. Entering the hovel, the king requests the fool take precedence, which foretells a budding compassion for him, and he prays for "poor naked wretches" who have no roof over their "houseless 
heads and unfed sides" (Shakespeare, 2009, 3, 4, 324). Such alteration in his behavior is characteristic of a transformation in him from an unbending and obstinate man into a sensitive sympathizer of man's common humanity, as well as a man downgrading the superficiality of rank and power. Bordering on identity loss, Lear retains an openness of mind to unite with nature and human suffering:

Oh, I have ta'en

Too little care of this! Take physic, pomp.

Expose thyself to feel what wretches feel,

That thou mayst shake the superflux to them

And show the heavens more just. (Shakespeare, 2009, 3, 4, 37-41)

This simplicity and directness of communication are not attained otherwise the egoistic self is supplanted by a fluid one, which feels the sufferings of others and so is inspired to benevolent acts. The moment King Lear asks, "Who is it that can tell me who I am?" he has already set off on a journey towards telltale questions regarding the nature of human being. $\mathrm{He}$ asks the naked Edgar an erudite question, indicating Lear's gradual awareness of the underlying layers in human nature: "Is man no more than this? Consider him well. - Thou owest the worm no silk, the beast no hide, the sheep no wool, the cat no perfume" (Shakespeare, 3, 4, 109-12). The then king now compliments nakedness because it releases one of indebtedness to animals for their silk, leather, or wool and even perfume. The king tears off his clothes to come closer to Edgar's state who is no more than a poor, naked 'animal'. In scene six of act three, Lear visualizes a trial of Goneril and Regan before a tribunal made up of Edgar, the fool, Kent and himself, and he is swiftly followed by Edgar and the fool, who are deeply respected as "most learned justice" and "sapient sir" respectively (Shakespeare, 3, 6, 21-2). To our astonishment, two fools are regarded in considerable respect, which indicates the cultivation of his newly acquired attitude of mind. Beyond the new attitude, Lear is the man subject to a world of pains and troubles, which school his intelligence via a journey by which he transcends the "egotistical sublime" - the phrase Keats coins as a censure against William Wordsworth's exceeding subjectivity.

Prompted by Gloucester's blindness, Lear imparts substantial growth of his capacity for absorbing a modified, integrated knowledge of human potential:

What, art mad? A man may see how this world goes with no eyes. Look with thine ears. See how yon justice rails upon yon simple thief. Hark in thine ear: change places and, handydandy, which is the justice, which is the thief? Thou hast seen a farmer's dog bark at a beggar? (Shakespeare, 4, 6, 165-70)
Ironically speaking in the king's case, madness conjures up a vision whereby a man can see with no eyes but with ears. Unbound from his comfortable egotistical enclosure, King Lear assumes a metamorphic identity. He transcends his willful blindness and recognizes that "I am a man / More sinned against than sinning" (Shakespeare, 2009, 3, 2, 62-3); it is not his majesty to be sinned against but just a man banished from his homeland. King Lear helplessly utters a declaration of his majesty that "I am the king himself' (Shakespeare, 2009, 4, 6, 102-3). Yet soon follows an assertion of his gullibility after he fathoms the deceit his two daughters practiced, "They flattered me like a dog and told me I had white hairs in my beard ere the black ones were there [...] they told me I was everything. 'Tis a lie. I am not ague-proof' (Shakespeare, 2009, 4, 6, 115-17, 123-24). In this speech, his self-perception vacillates between the extreme of his bygone kingship and the ongoing recognition of his disastrous frailty.

Prior to his banishment and exposure to such pains, King Lear delineates distinctions between himself and his subjects, "when I do stare, see how the subject quakes" (Shakespeare, 2009, 4, 6, 128), but he then pardons a man's life and "thou shalt not die" (Shakespeare, 2009, 4, 6, 130), even for adultery, since - in Keats's terms - his vision is sharpened. The marked distinctions between him and his subjects progressively fade away with his self-centeredness being annihilated, which is typical of negative capability. King Lear unbinds the fetters of regal excellence and inveighs against his own self and the absurdity of the world.

In a letter to George and Georgiana Keats in 1819, Keats proposes a metaphor of nature about the necessity of suffering to reach perfectibility in nature: "Let the fish Philosophise the ice away from the Rivers in winter time, and they shall be at continual play in the tepid delight of summer" (Keats, 1899, 369). With the winter ice melting, the delight of summer welcomes the fish after a period of gloom. Poets - metaphorically the fish - remove the ice from the rivers so that they will enjoy the summer light. They, according to Keats, should dismiss their selfmade and static enclosure and expose themselves to metamorphic, dynamic and fluid identities, so they will break from egotism in pursuit of intelligible sympathy. Negative capability comparably might "develop from something self-delighting into a comprehensive and painful sympathy," with the discomforts and suffering being "imposed from outside the identity" (White, 1987, pp. 191-2). King Lear does away with the kingly majesty to benefit from the tepid delight of summer in the prison he demands forgiveness: 
No, no, no, no. Come, let's away to prison. We two alone will sing like birds i' th' cage. When thou dost ask me blessing, I'll kneel down And ask of thee forgiveness. So we'll live, And pray, and sing, and tell old tales, and laugh At gilded butterflies, and hear poor rogues Talk of court news, and we'll talk with them too. (Shakespeare, 2009, 5, 3, 9-15)

Henceforth the prison is preferable to him than the court. Lear gradually comes to grips with his seeming diminish of wits: "My wits begin to turn" (Shakespeare, 2009, 3, 2, 73). Yet, his wits begin to turn into sophistication, not into unpolished insanity. As Lear begins to attend to others, so the fool's role withers away and from act 4 onwards, we do not hear of the fool, because he has always been Lear's foil. The fool sifts through the goings-on and relates them to the grim realities by means of his humorous language. He dares call the king a fool after Lear asks him "Dost thou call me fool, boy?" (Shakespeare, $2009,1,4,152)$, and he does not hesitate to affirm that "all thy other titles thou hast given away that / thou wast born with" (Shakespeare, 2009, 1, 4, 153-4). He rebukes splitting up the kingdom because the king is now "an O without a figure" and the fool claims, "I am better than thou art now. I am a Fool. Thou are nothing" (Shakespeare, 2009, 1, 4, 198-9). Lear is now zero. Nevertheless, when the King's wits begin to turn in earnest, the Fool's fooling pales by comparison and after absorbing the fool's truths, Lear starts to utter them himself and the fool's role becomes superfluous. The fool is an outsider within the court, but it is the fool audaciously telling the truths. Banished and cast away, King Lear assumes an outsider merits and enjoys a similar vision to face up to the truth unseen for so long. He crosses selfcenteredness borders and enters into "uncharted regions of mind where much madness is divinest sense" (Calderwood, 1986, p. 10). After substituting the fool's role, Lear's rhetoric turns into wisdom and sophistication indicative of his negatively capable mind. After experiencing spasmodic flashes of negative capability, King Lear reaches beyond the limitations of his individuality. $\mathrm{He}$ becomes negatively capable of transcending his egoistic and enclosed self to augment his receptivity to the actual vastness and complexity of life experience.

\section{CONCLUSION}

King Lear initially represents an egoistic character, who shows no flexibility towards necessary changes. After being cast away and wandering as an outsider, he begins an experiential journey of self-awareness. According to Keats, he should undergo 'a world of pains and sorrows' to attain a sharpened vision into the heart and nature of Man. He, then, gains a fresh self-perception, allowing him to cast off his egoistic self and take on an elastic self by means of negative capability.

\section{REFERENCES}

Bate, W. J. (1958). The stylistic development of Keats. London: Routledge \& Kegan Paul.

Benton, Richard. P. (1966). Keats and Zen. Philosophy East and West, 16, 33-47.

Calderwood, James. L. (1986). Creative uncreation in King Lear. Shakespeare Quarterly, 37 (1), 5-19.

De Man, Paul. (1996). Aesthetic ideology. Minneapolis: University of Minnesota Press.

Engell, James. (1981). The creative imagination: enlightenment to romanticism. Cambridge, Mass.: Harvard Univ. Press.

Fay, Elizabeth A. (1998). A feminist introduction to romanticism. Malden, Mass.: Blackwell.

Foakes, R. A. (1994). Hamlet versus Lear: Cultural politics and Shakespeare's art. Cambridge: Cambridge University Press.

Han, Kwang-Sok. (2010). The ontological vision of nothing and realization of the true self in King Lear. The Journal of East-West Comparative Literature, 22, 247-270.

Hazlitt, William and Hunt, Leigh. (1991). The round table: 1817. Oxford: Woodstock Books.

Keats, John. (2002). Selected letters. Ed. Robert Gittings. Oxford World's Classics. Oxford University Press.

---. (1899). The complete poetical works and letters of John Keats. Ed. Horace E. Scudder. Boston: Houghton Mifflin and Company.

$\mathrm{Ou}, \mathrm{Li}$. (2009). Keats and negative capability. London: Continum. eBook Super CollectionAustria. Web. 28 Feb. 2016.

Sandy, Mark. (2005). Poetics of self and form in Keats and Shelley: Nietzschean subjectivity and genre. Aldershot: Ashgate.

Schoff, Francis, G. (1962). King Lear: moral example or tragic protagonist. Shakespeare Quarterly, 13(2), 157-72.

Shakespeare, William. (2009). The tragedy of King Lear. Ed. Barbara A. Mowat and Paul Werstine. New York: Simon \& Schuster Paperbacks.

Whale, John. (2005). John Keats (critical issues). Basingstoke: Palgrave Macmillan.

White, R. S. (1987). Keats as a reader of Shakespeare. London: The Athlone Press 